\title{
Characterization of Kudzu (Pueraria spp.) Resistance to Phakopsora pachyrhizi, the Causal Agent of Soybean Rust
}

\author{
Stephen A. Jordan, Daniel J. Mailhot, Amanda J. Gevens, Jim J. Marois, \\ David L. Wright, Carrie L. Harmon, and Philip F. Harmon
}

First and third authors: Department of Plant Pathology, University of Wisconsin, Madison 53706; and second and fourth authors: North Florida Research and Education Center, fifth author: Department of Agronomy, North Florida Research and Education Center, and sixth and seventh authors: Department of Plant Pathology, University of Florida, IFAS, Gainesville 32611.

Accepted for publication 5 May 2010.

\begin{abstract}
Jordan, S. A., Mailhot, D. J., Gevens, A. J., Marois, J. J., Wright, D. L., Harmon, C. L., and Harmon, P. F. 2010. Characterization of kudzu (Pueraria spp.) resistance to Phakopsora pachyrhizi, the causal agent of soybean rust. Phytopathology 100:941-948.

Kudzu (Pueraria spp.) is an accessory host for soybean rust (SBR) (caused by Phakopsora pachyrhizi) that is widespread throughout the southeastern United States. An expanded survey of kudzu sites was conducted in 2008 to determine the proportion of natural resistance in the north-Florida kudzu population. Of the 139 sites evaluated, $\approx 18 \%$ were found to be free of SBR infection, while $23 \%$ had reduced sporulation. Ten accessions of kudzu from north-central Florida were characterized for their response to challenge by a single isolate of $P$. pachyrhizi under laboratory conditions. Three outcomes were observed: tan lesions with

profuse sporulation (susceptible); reddish-brown lesions with delayed, reduced sporulation (resistant); and an immune response in which no lesions developed (immune). Of the 10 accessions, 6 were susceptible, 3 were immune, and 1 was resistant. Cytological examination revealed that resistant interactions were typified by early onset of a multicell hypersensitive response (HR) while typical immune interactions were the result of cell wall depositions that blocked penetration in combination with early onset of the HR. Quantitative real-time polymerase chain reaction was performed to determine the extent of colonization. After 15 days, there was 10-fold less $P$. pachyrhizi DNA present in resistant compared with susceptible kudzu, while the amount of $P$. pachyrhizi DNA present in the immune kudzu was below the detection level. Susceptible kudzu had approximately half the amount of $P$. pachyrhizi DNA present when compared with a susceptible soybean cultivar.
\end{abstract}

Soybean rust (SBR) is caused by the fungus Phakopsora pachyrhizi Syd. \& P. Syd. Originating in Asia, SBR has gradually spread across the world, reaching the United States in 2004 $(2,23,34)$. P. pachyrhizi is a microcyclic rust, with urediniospores acting as the primary disease propagule. Teliospores have been found on both soybean (Glycine max L.), its primary host, and kudzu (Pueraria spp.) in the United States (20). The biological role of teliospores is unknown, because an alternate host has not been found (25).

Although the disease has caused little damage to soybean crops in the United States (7), the potential yield loss and cost of managing the disease is significant. In Taiwan, yield losses of up to 70 to $80 \%$ have been reported and, in Brazil, the cost of controlling the disease totals in the billions $(4,43)$. It has been estimated that yield losses in the United States could exceed $10 \%$, with a potential yield loss of $>50 \%$ in the southeastern states (42). Unlike most rust fungi, $P$. pachyrhizi has a broad host range, including at least 95 legume species in over 42 genera $(6,32)$. In the United States, the most important accessory host is kudzu.

Kudzu is a perennial, semiwoody, climbing leguminous vine with trifoliate leaves. It can grow quickly in poor, sandy soil with intermediate shade and can be difficult to control, often requiring multiple applications of herbicide over several years for eradication (26). Although native to China and Japan, it was originally introduced into the United States as an ornamental vine in 1876 at the Philadelphia Centennial Exposition (41). Kudzu first gained popularity as a forage crop at the beginning of the 20th century

Corresponding author: P. F. Harmon; E-mail address: pfharmon@ufl.edu

doi:10.1094/PHYTO-100-9-0941

(C) 2010 The American Phytopathological Society
(30) but did not receive widespread distribution until the 1930s and 1940s, when it was promoted by the United States Department of Agriculture Soil Conservation Service for soil erosion control (39). In 1953, kudzu was recognized as a weed and removed from the list of species recommended for use under the Agricultural Conservation Program (38). By 1970, it was listed as a common weed in the southeastern United States (14) and is currently listed as a noxious weed in at least nine states (38). Estimates of the kudzu infestation in the United States vary, ranging from 2 to over 10 million acres $(9,15,27,28)$. Currently, kudzu has been reported in 32 of the 50 states, including states as far north as Wisconsin and North Dakota (40).

Kudzu is a serious concern for soybean producers due to the potential role of SBR-infected kudzu in SBR epidemics on soybean as well as its status as the most likely overwintering host of SBR in the continental United States (22). Soybean rust can survive year-round in central Florida on kudzu and urediniospores can survive for a short period of time on abscised leaves (22). The potential for SBR survival on nonleaf tissue has yet to be determined. Accessions of kudzu have been found in the United States that are resistant to SBR, displaying the same reaction or lesion types that are displayed in soybean: susceptible tan lesions, resistant red or brown lesions, and an immune response where no lesions develop (7). The cytology of the interaction of pathogen and host has yet to be studied for these reaction types.

The prevalence of SBR-resistant kudzu in the United States is currently unknown. Work carried out on kudzu from Mississippi, Louisiana, Kentucky, and North Carolina provided the first insight into the relative frequency of susceptible and resistant kudzu in the southeastern United States (7). Prior to this study, the kudzu population in Florida had not been examined. Considering the likelihood of Florida kudzu serving as a source of overwintering 
and subsequent source of inoculum in the spring and summer, an understanding of the prevalence and type of resistance is of critical importance.

With the possibility of kudzu serving as an early-season host of SBR, kudzu sites have been monitored in north Florida since 2005. During this period, some observed sites never became diseased, despite close proximity to positive sites (unpublished data). Noninfected kudzu sites were widely dispersed and shared no obvious environmental characteristics. The purpose of this study was to determine whether minimally symptomatic and disease-free sites of kudzu contain resistant to SBR and, if so, identify the nature of the resistance. The objectives of this study were to (i) characterize symptom development on inoculated leaves from historically infected or noninfected sites, (ii) estimate the prevalence of SBR-resistant kudzu in north Florida, and (iii) examine the interaction between the pathogen and kudzu accessions at the cellular level.

\section{MATERIALS AND METHODS}

Kudzu scouting program and population susceptibility screening. Kudzu sites in north Florida were monitored for the presence of P. pachyrhizi beginning in 2005. The number of sites monitored per county varied from two to nine during the first year, and additional sites were added in subsequent years. Two coastal counties in north Florida were excluded because kudzu has not been detected there. Sites were typically checked in the spring and on a monthly basis until defoliation due to frost. Apparently healthy leaflets were sampled from each scouted site at 2-week intervals for three sampling dates per year. The middle leaflet of the fifth trifoliate leaf from the end of a vine was collected for each site and collection date. In all, 6 leaflets which developed in full sunlight and 6 from full-shade areas were collected for a total of 12 leaflets per site and date. Five of the six leaflets from each site were inoculated and one was left as a noninoculated control. Sampled leaflets were sealed in plastic bags to prevent desiccation and kept cool $\left(\approx 10^{\circ} \mathrm{C}\right)$. In the laboratory, the upper and lower sides of each leaflet were rinsed two times with $23^{\circ} \mathrm{C}$ running tap water to dislodge contaminants. Leaves were dried with a paper towel prior to inoculation.

A mixed population of urediniospores of $P$. pachyrhizi were collected from naturally infected soybean plants at the North Florida Research and Education Center in Quincy, FL, during the period in which this study was conducted. Spores were stored in microcentrifuge tubes at $-80^{\circ} \mathrm{C}$ prior to preparation of inoculum suspensions. Prior to inoculation, spores were suspended in $0.2 \%$ ( $\mathrm{vol} / \mathrm{vol}$ ) Tween 20 in sterile distilled water adjusted to a concentration of 8,000 spores $/ \mathrm{ml}$ using a hemacytometer. A new suspension was created each day, immediately before inoculating leaves. A KC-566CG paint sprayer (Lowes, North Wilkesboro, NC) was used to inoculate the upper surface of each leaf using $0.5 \mathrm{ml}$ of suspension. The suspension was also sprayed on a plate of water agar and incubated to assess spore germination. After inoculation, the petiole of each leaflet was cut diagonally with a scalpel to produce a clean, fresh surface. Each leaflet was then placed in an individual petri dish (150 by $15 \mathrm{~mm}$ ) half filled with $1 \%$ water agar, with the petiole inserted into the agar to keep the leaflet from desiccating. No plant hormones were utilized. Petri dishes were kept at room temperature $\left(\approx 24^{\circ} \mathrm{C}\right)$ and exposed to ambient laboratory lighting. Leaves were monitored for symptom development until sporulation was detected or 28 days from inoculation. Data collected included number and appearance of lesions and presence or absence of sporulation. Sample leaves were obtained from 119 additional kudzu sites in north Florida in the summer of 2008. Each site was sampled once during the season. Six leaflets that matured in direct sunlight were used for each sampling. Inoculations and symptom evaluation were performed as described above.
Kudzu accessions, soybean line, and fungal material. Ten accessions of kudzu were collected from sites in north-central Florida in the spring of 2007 by digging up a healthy, asymptomatic root and vine from each location. The following accessions were included in this study: from Alachua County: FLAL01, FLAL09, FLAL10, FLAL11, FLAL12, FLAL13, FLAL14, FLAL15; and from Marion county: FLMA01 and FLMA04. The accessions were planted in 5-gal. plastic pots containing Metro Mix 300 potting soil (Sun Gro Horticultural Distributors, Inc., Bellevue, WA) and maintained in a rust-free glass greenhouse without shading on the Gainesville campus of the University of Florida. Accessions were propagated clonally by layering, in which a node from a vine from a mother plant was buried in soil $\approx 1$ in. deep. Once rooting had taken place, the attached vine was cut between the propagated clone and the mother plant.

The isolate of $P$. pachyrhizi (FL05) used in this study was collected from an infected soybean in the summer of 2005 from the Plant Science Research and Education Center near Citra, FL. The isolate has been maintained on soybean genotype 5N327RR (Mycogen, Dow Agrosciences) in a greenhouse on the Gainesville campus of the University of Florida.

To prepare spores for inoculation, mature urediniospores were collected by vacuum cyclone separation from the underside of infected soybean leaves growing in a greenhouse. Spores were suspended in a solution of $0.2 \%$ ( $\mathrm{vol} / \mathrm{vol}$ ) Tween 20 in sterile distilled water and gently mixed for 20 to $30 \mathrm{~s}$ using a vortexer. Urediniospore concentration was determined using a hemacytometer prior to adjusting to a final concentration.

Kudzu accession detached-leaf assay. Detached leaflets were excised from either the second or third node (immature) and from the sixth node (mature) of kudzu accessions growing in the greenhouse. Detached leaflets were brought back to the laboratory, rinsed with sterile distilled water, pat dried with a sterile paper towel, and placed in petri dishes on top of $1 \%$ agar. Each leaflet (four mature and four immature of each accession, each taken from different leaves) was inoculated on its upper surface in 9 to 10 spots with $5 \mu \mathrm{l}$ of a urediniospore suspension $\left(10^{4}\right.$ spores $/ \mathrm{ml}$ ) prepared as described previously. Leaflets were placed in the dark at $22^{\circ} \mathrm{C}$ overnight and then maintained for the duration of the assay under constant fluorescent lighting at $22^{\circ} \mathrm{C}$. At 10 , 15 , and 20 days postinoculation (DPI), leaf discs were removed from the detached leaflets at the sites of inoculation using a cork borer and placed individually in $1.5-\mathrm{ml}$ microcentrifuge tubes. Then $100 \mu \mathrm{l}$ of $0.2 \%$ ( $\mathrm{vol} / \mathrm{vol}$ ) Tween 20 in sterile distilled water was added to each tube, followed by gentle mixing for $30 \mathrm{~s}$ using a vortexer. Spore concentration was determined for each leaflet using a hemacytometer. The number of spores produced at each inoculation site was determined using the spore concentration and collection volume. In all, 3 inoculation sites were harvested from each leaflet at each time point, giving a total of 12 sites for each age and 24 sites for each accession at each time point. The assay was carried out twice and statistics were applied to the data using the proc GLM method in SAS (33).

Greenhouse inoculations. Three accessions of kudzu (one representing each phenotype: susceptible, resistant, and immune) and a susceptible soybean genotype (5N327RR) were selected for whole-plant inoculations. The kudzu plants were 4 to 6 months old and the soybean plants were $\approx 1$ month old at the time of inoculation. Four plants of each accession were sprayed to run-off with a urediniospore suspension $\left(10^{5}\right.$ spores $\left./ \mathrm{ml}\right)$ prepared as described above. Four mature leaflets from each plant were detached and brought back to the laboratory for analysis 10,15 , and 20 DPI. Leaf discs of $1 \mathrm{~cm}^{2}$ were removed from three random spots on each leaflet using a cork borer. Total number of lesions, number of pustules per lesion, and lesion diameter were recorded using a Leica MZ16 dissecting microscope (Leica Microsystems $\mathrm{GmbH}$, Wetzar, Germany) and QCapture Pro software (QImaging, Surrey, BC, Canada). Total spore production was measured for 
each leaf disc as described previously. The experiment was repeated.

Histological analysis and classification of infection sites. Detached leaflets, taken from the fifth or sixth node from the tip, were placed in petri plates containing $1 \%$ solid agar and were misted to run off with a urediniospore suspension $\left(10^{5}\right.$ spores $\left./ \mathrm{ml}\right)$ prepared as described previously. Sections $\left(1 \mathrm{~cm}^{3}\right)$ were harvested at $12,24,48,72,96$, and $120 \mathrm{~h}$ postinoculation and stained and fixed by submerging the sections in a solution of $0.05 \%$ trypan blue in 1:2 (vol/vol) lactophenol/ethanol. Sections were boiled for $1 \mathrm{~min}$ and then kept at room temperature overnight in the staining solution. Sections were destained and further cleared in saturated chloral hydrate $\left(2.5 \mathrm{~g} \mathrm{ml}^{-1}\right)$ for several days. Sections were stored in chloral hydrate until examination. Plant and fungal structures were observed using a Leica Dialux 20 microscope and images were taken using a Qimaging MicroPublisher 3.3 RTV camera. Three to five leaflets were analyzed for each accession, and $\approx 50$ to 100 interactions were observed and recorded per leaflet.

Quantitative real-time polymerase chain reaction. Detached leaflets, taken from the fifth or sixth node from the tip, were placed in petri plates containing $1 \%$ water agar followed by misting until run-off with a urediniospore suspension $\left(10^{5}\right.$ spores $\left./ \mathrm{ml}\right)$ prepared as described previously. At 1, 3, 5, 10, and 15 DPI, three $1-\mathrm{cm}^{2}$ leaf sections were removed from each accession with a cork borer, individually placed in $1.5-\mathrm{ml}$ microcentrifuge tubes, and frozen in liquid nitrogen until extraction. DNA was isolated from the inoculated leaf tissue using the Sigma RED Extract-NAmp Plant polymerase chain reaction (PCR) Kit (Sigma-Aldrich, St. Louis), following the manufacturer's instructions. Genomic DNA from $P$. pachyrhizi was extracted from a urediniospore suspension of isolate FL05 using the method described by Pitken et al. (31).

Oligonucleotide primers specific to $P$. pachyrhizi, ppm1 (GCAGAATTCAGTGAATCATCAAG) and ppa2 (GCAACAC TCAAAATCCAACAAT) (19), were labeled at their 5' end with the fluorescent reporter dye 6-carboxy-fluorescein (FAM) and at their $3^{\prime}$ end with the quencher dye 6-carboxytetramethyl-rhodamine (TAMRA). Reactions were performed in a $25-\mu l$ final volume containing $2 \mu \mathrm{l}$ of sample DNA and $23 \mu \mathrm{l}$ of master mix containing 1× OmniMix HS lyophilized PCR master mix (Takara Bio Inc., Otsu, Shiga, Japan) and $1.0 \mu \mathrm{M}$ each primer. Amplification was performed using a Smart Cycler II (Cepheid, Sunnyvale, CA). The amplification protocol included an initial denaturation at $95^{\circ} \mathrm{C}$ for 2 min followed by 35 two-step cycles of $94^{\circ} \mathrm{C}$ for $5 \mathrm{~s}$ followed by $60^{\circ} \mathrm{C}$ for $60 \mathrm{~s}$. Absolute quantification of DNA in quantitative real-time (q)PCR was accomplished using standard curves of known concentrations of DNA. In this study, standard curves were generated using $1: 10^{\mathrm{x}}$ serial dilutions $(100$ to $0.01 \mathrm{ng} / \mu \mathrm{l})$ of the $P$. pachyrhizi DNA spiked with DNA extracted from healthy kudzu. Absolute DNA concentration was determined by plotting the point at which the sample reached the threshold cycle $(\mathrm{Ct})$ on the standard curve.

\section{RESULTS}

Kudzu scouting program and population susceptibility screening. Inoculations of leaves from 10 historically noninfected kudzu sites resulted in lesions and pustules on those collected at one site. Leaves from six sites produced lesions without sporulation and, on those from three sites, no lesions or sporulation were observed. Of the 10 sites where infections were previously observed during scouting, leaves from all 10 produced lesions but only 9 sporulated. The number of lesions and presence of sporulating pustules did not differ $(P \geq 0.05)$ between leaves that matured in sun (13.7 lesions $\left./ \mathrm{cm}^{2}\right)$ compared with shade conditions (12.2 lesions $\left./ \mathrm{cm}^{2}\right)$. Sites differed in total area, soil type, terrain, and size and shape of leaves but these factors did not appear to be associated with susceptibility to infection.

Lesions were noted on inoculated leaves from $\approx 94 \%$ of the kudzu sites. Sporulation failed to occur on leaves from $\approx 18 \%$ of sites (25 sites total), while sporulation was light (1 to 25 lesions/ $\mathrm{cm}^{2}$ ) from $23 \%$ of the sites (32 sites). The majority of sites (59\%,
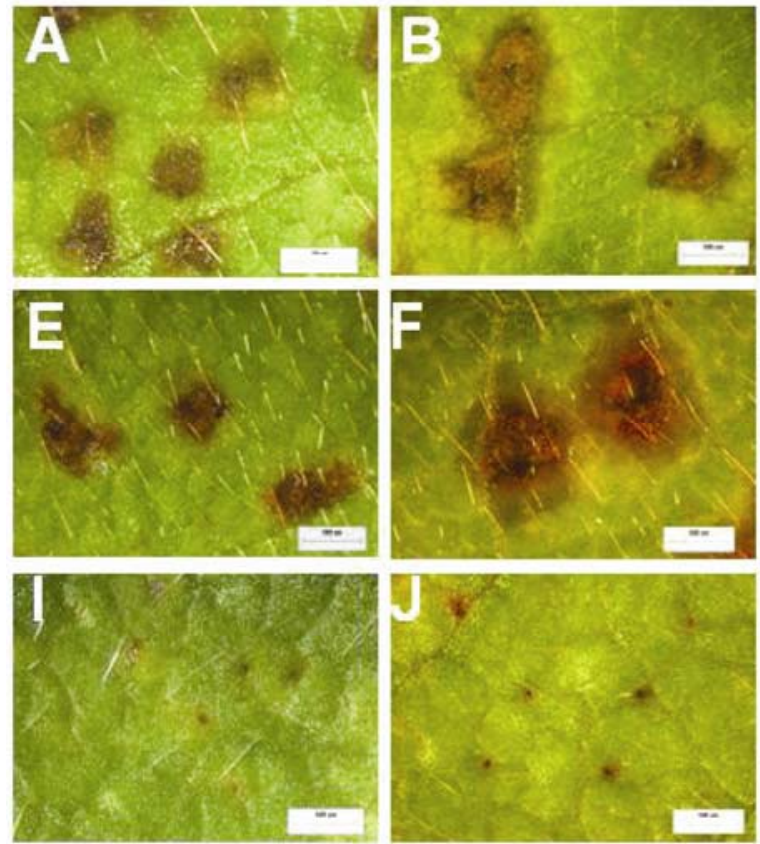
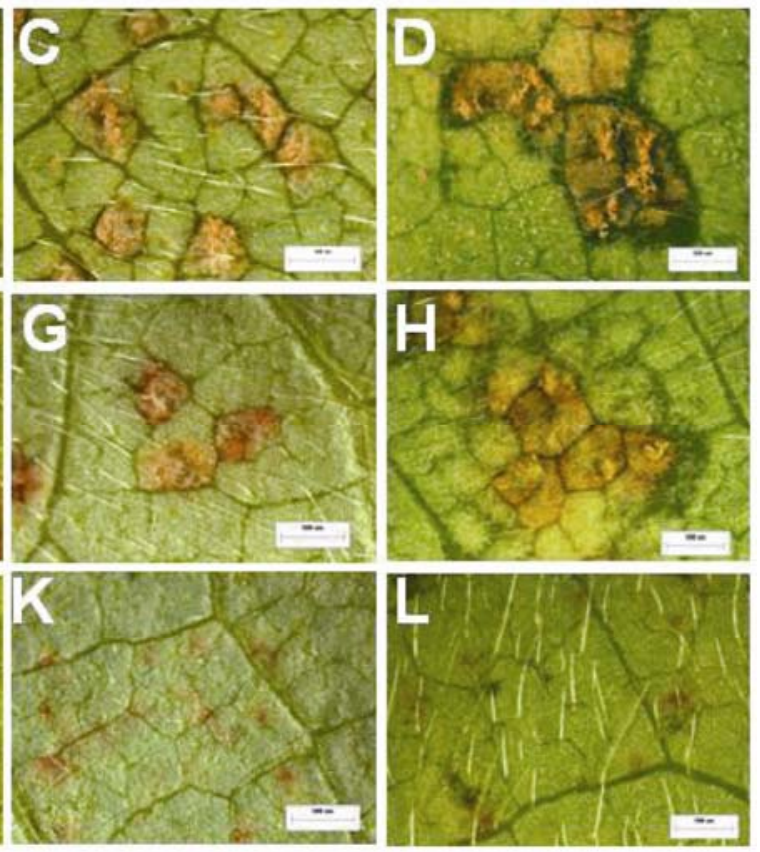

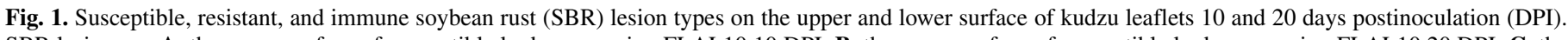

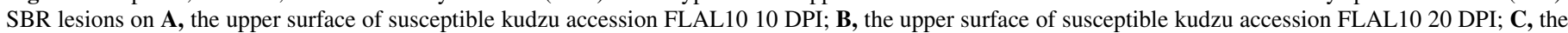

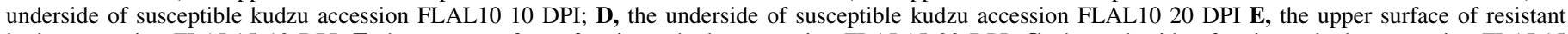

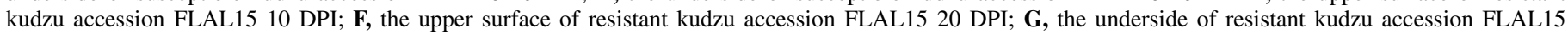

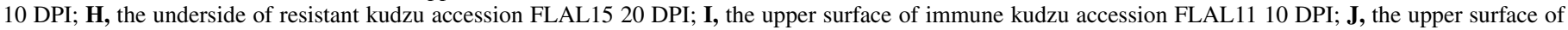

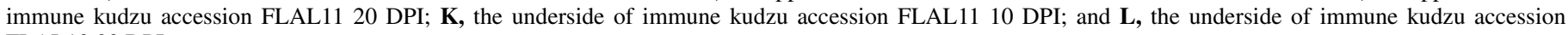
FLAL10 20 DPI. 
82 sites total) had moderate to heavy sporulation (>25 lesions/ $\mathrm{cm}^{2}$ ). These sporulation results using the detached-leaf assay support disease scouting data collected in 2005 to 2008 .

Kudzu accession detached-leaf assay. There was no significant difference within each kudzu accession when comparing the spore production on mature and immature leaflets (data not shown; $F$ was not significant at $P=0.5218$ ). Consequently, data for mature and immature leaflets were pooled for comparison between isolates. Of the 10 accessions assayed, 3 (FLAL01, FLAL09, and FLAL11) either did not produce discernable lesions or produced small, dark flecks on the surface of the leaflet, indicating an immune response (Fig. 1). One of the accessions, FLAL15, produced primarily reddish-brown lesions, typically representative of a resistant genotype in soybean and kudzu (Fig. 1). The other six accessions produced tan lesions representative of a susceptible genotype in soybean and kudzu (Fig. 1).

The immune accessions did not support production of urediniospores at any time in the assay (Fig. 2) and only necrotic flecking could be seen on the underside of the leaflet (Fig. 1K and L). The resistant accession (FLA15) did not contain urediniospores at 10 DPI but immature uredinia formed on the underside of the lesions (Fig. 1G). At 15 DPI, $187.5 \pm 62.5$ (mean and standard error) urediniospores were produced per inoculation site, and by $20 \mathrm{DPI}$, the number of urediniospores increased to $1937.5 \pm$ 134.0. The susceptible accessions produced sporulating uredinia on the underside of the lesions by 10 DPI, with an average of 817.7 urediniospores per infection site, increasing to 3,052.1 at 15 DPI and 4,359.4 at 20 DPI (Fig. 2).

Greenhouse inoculations. Lesion densities on soybean and susceptible kudzu (FLAL10) were approximately the same, with the resistant kudzu having approximately half as many lesions (Fig. 3A). The immune phenotype did not produce true lesions but produced low numbers of small brown flecks that were recorded as lesions (Fig. 3A). The lesion density for all of the kudzu accessions and soybean did not change over time.

The size of lesions on the susceptible kudzu accession (FLAL10) increased from 10 to 20 DPI, and was initially smaller than both the soybean and the resistant kudzu (FLAL15) but, by 20 days, was slightly larger in size than the other two (Fig. 3B). The immune accession had only small flecks, consisting of only a few necrotic cells (Fig. 3B).

The number of uredinia per lesion was highest at all time points on the soybean when compared with the accessions of kudzu (Fig. 3C). The resistant kudzu accession (FLAL15) was just beginning

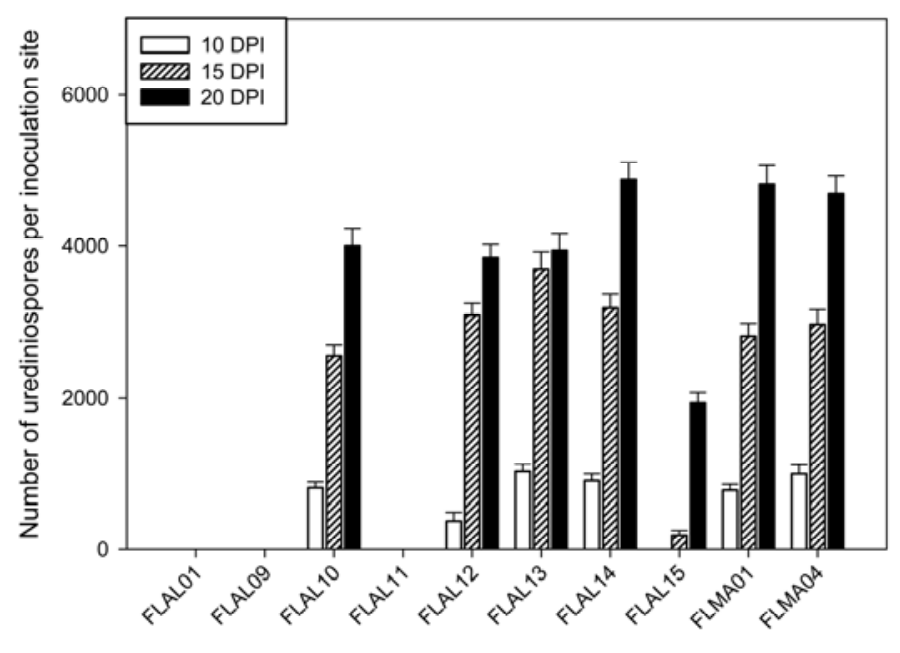

Kudzu accession

Fig. 2. Total urediniospore production on detached kudzu leaflets from kudzu accessions 10, 15, and 20 days postinoculation (DPI). Variation in data sets is displayed as standard error bars. to produce uredinia at $10 \mathrm{DPI}$ but, by $20 \mathrm{DPI}$, had approximately half the number of uredinia per lesion compared with the soybean and significantly fewer than the susceptible kudzu (FLAL10) (Fig. 3C). The immune kudzu accession (FLAL11) did not produce any uredinia at any time in the study (Fig. 3C).

The number of urediniospores produced per uredinium was highest in the soybean but the susceptible kudzu accession (FLAL10) had similar numbers (Fig. 3D). The resistant kudzu accession (FLAL15) did not have a measurable number of urediniospores at $10 \mathrm{DPI}$, and had less than half the number of urediniospores per uredinia by the end of the study (Fig. 3D). No urediniospores were produced on the immune accession (FLAL11).

Microscopic analysis and classification of infection sites. The initial infection and colonization of three accessions, representing the susceptible (FLAL10), resistant (FLAL15), and immune phenotype (FLAL11), were examined microscopically alongside a susceptible soybean cultivar (5N327RR). Urediniospores germinated and produced appressoria that were approximately the same diameter as the spore, typically within $12 \mathrm{~h}$ of inoculation (Fig. 4A). Penetration occurred directly into the epidermal cell, with no preference shown for infection through a stoma. Upon penetration, a large infection hypha formed within the epidermal cell and easily could be seen at 16 to $24 \mathrm{~h}$ for all host-pathogen interactions (Fig. 4B).

Susceptible interaction. In the interaction between FLAL10 and SBR isolate FL05, hyphae and haustoria were present within the upper layer of the mesophyll by $24 \mathrm{~h}$ after inoculation (Fig. 4C). At $48 \mathrm{~h}$, the penetrated epidermal cell became discolored but this discoloration did not extend beyond the epidermal cell (Fig. 4D). At this point, the initial penetration and infection processes in FLAL10 were identical to those in the susceptible soybean. For both the susceptible soybean and the susceptible kudzu accession, penetration of the cell resulted in colonization of the mesophyll and formation of haustoria in $100 \%$ of the interactions observed (Fig. 5). By $120 \mathrm{~h}$, extensive colonization of the entire mesophyll could be seen in the susceptible soybean (Fig. 4E) but was more limited in comparison with the susceptible kudzu (Fig. 4F). Occasionally, hyphae would grow out of the stoma of FLAL10 (Fig. 4G), a phenomenon not seen in the interaction between FL05 and the susceptible soybean.

Resistant interaction. Between 24 and $48 \mathrm{~h}$ after inoculation, a noticeable hypersensitive response (HR), observed initially as granulation and a brown discoloration of the cell, occurred in the epidermal cell (Fig. $4 \mathrm{H}$ ). In $\approx 70 \%$ of the interactions (Fig. 5), the same response was also observed in cells of the palisade mesophyll below the penetrated epidermal cell (Fig. 4I) as well as in some epidermal cells surrounding the penetrated epidermal cell (Fig. 4J). There were no visible haustoria $48 \mathrm{~h}$ after inoculation, possibly due to the discoloration produced by the HR and, by $120 \mathrm{~h}$ after inoculation, there was very little colonization of the mesophyll.

Immune interaction. Early onset of an HR was observed in the infected epidermal cell in the interaction of the rust isolate FL05 with the immune kudzu (FLAL11), similar to the resistant interaction. However, within these cells, a cell wall deposition (CWD), appearing to originate from the epidermal cell wall, formed around the penetration hyphae (Fig. $4 \mathrm{~K}$ ). In $\approx 70 \%$ of these interactions, no visible HR occurred in surrounding cells (Fig. 5), and no further signs or symptoms of infection were observed in the mesophyll at later time points. In $\approx 20 \%$ of the FL05-FLAL11 interaction, a multiple-cell HR could be seen, primarily in surrounding epidermal cells (Fig. 4L) Also, additional CWD could be seen occasionally abutting the inner periclinal wall in cells surrounding the infected cell (Fig. 4L). A small percentage of infected epidermal cells did not have a visible CWD but did exhibit an HR (Fig. 5). Escape of the infection hypha from a CWD occurred in $\approx 5 \%$ of interactions but typically resulted in a multi-cell HR (Fig. 5). 
qPCR. At 1 and 3 DPI, the amount of fungal DNA present in the plant tissue was not sufficient to distinguish differences between the three kudzu accessions and the soybean (Fig. 6). By day 5, the soybean tissue had nearly eight times as much $P$. pachyrhizi DNA $(10.5 \mathrm{ng} / \mu \mathrm{l})$ as the susceptible kudzu accession (FLAL10) $(1.7 \mathrm{ng} / \mu \mathrm{l})$, whereas the resistant kudzu accession (FLAL15) (0.029 $\mathrm{ng} / \mu \mathrm{l})$ and the immune kudzu accession (FLAL11) $(0.004 \mathrm{ng} / \mu \mathrm{l})$ were relatively unchanged. By days 10 and 15 , the amount of $P$. pachyrhizi DNA in the soybean tissue had increased dramatically (43.7 and $54.8 \mathrm{ng} / \mu \mathrm{l}$, respectively), with twice as much $P$. pachyrhizi DNA as the susceptible kudzu ( 16.9 and $24.5 \mathrm{ng} / \mu \mathrm{l}$, respectively). The amount of $P$. pachyrhizi DNA increased in the resistant kudzu accession (3.0 and $4.2 \mathrm{ng} / \mu \mathrm{l}$, respectively) but was well below the amount measured in the soybean and susceptible kudzu. The immune kudzu had almost no P. pachyrhizi DNA (0.01 and $0.02 \mu \mathrm{g} / \mu \mathrm{l}$, respectively).

\section{DISCUSSION}

The reaction types observed with infections of $P$. pachyrhizi on the kudzu in this study were fairly consistent with those reported on soybean and kudzu; tan lesions in a susceptible interaction, red or brown lesions in a resistant interaction, and an immune reaction in which little or no lesion development was seen (57,10 ). Occasionally, lesion appearance was not consistent within the reaction types. Lesions were observed that were dark brownblack, green with yellow margins, contained water soaking, or combinations of these. The difference between the susceptible interaction and the resistant one is an HR response, typically multicellular, that limits and delays colonization of the plant tissue. In the susceptible interaction, the infected epidermal cell collapses several days after infection; however, this cell death is limited to the epidermal cell. In the resistant response, the HR can be seen $24 \mathrm{~h}$ earlier and typically affects the epidermal cell as well as mesophyll cells under the epidermal cell (Fig. 7). Interestingly, the HR seen in the immune reaction is typically limited to the epidermis. Occasionally, several epidermal cells will exhibit the HR, which can visibly be seen as a flecking on the leaf surface.

An HR is a defense response triggered by pathogen penetration of a plant cell, a phenomenon noted in many pathogen-host interactions. H. H. Flor described the inheritance of virulence in the rust Melampsora lini (16), and inheritance of resistance in the host flax (Linum usitatissimum) (17). This work became the model for the gene-for-gene theory in which a pathogen avirulence gene product is recognized by a host resistance gene product, resulting in a specific defense response (18). The genefor-gene hypothesis was used to describe resistance to $P$. pachyrhizi in G. canescens, a perennial legume native to Australia (11). Earlier studies $(12,13)$ had identified both race-specific and racenonspecific resistance in this host. Kudzu accessions from a number of southern states have been identified as having resistance to $P$. pachyrhizi $(6,7,29)$. Hoefle et al. (21) observed a hypersensitive cell death reaction when $P$. pachyrhizi was inoculated on barley, a nonhost. Although appressoria formation and epidermal cell penetration occurred, penetration of the periclinal cell walls failed, and this failure was associated with the presence of callose.

This is the first report of a CWD in kudzu in response to infection by $P$. pachyrhizi. The CWD that occurs in the immune response appears to be important in limiting the ingress of the pathogen. The composition of the CWD is currently unknown but the primary component is likely callose. Callose has long been implicated in plant defense by reinforcing the plant cell wall at
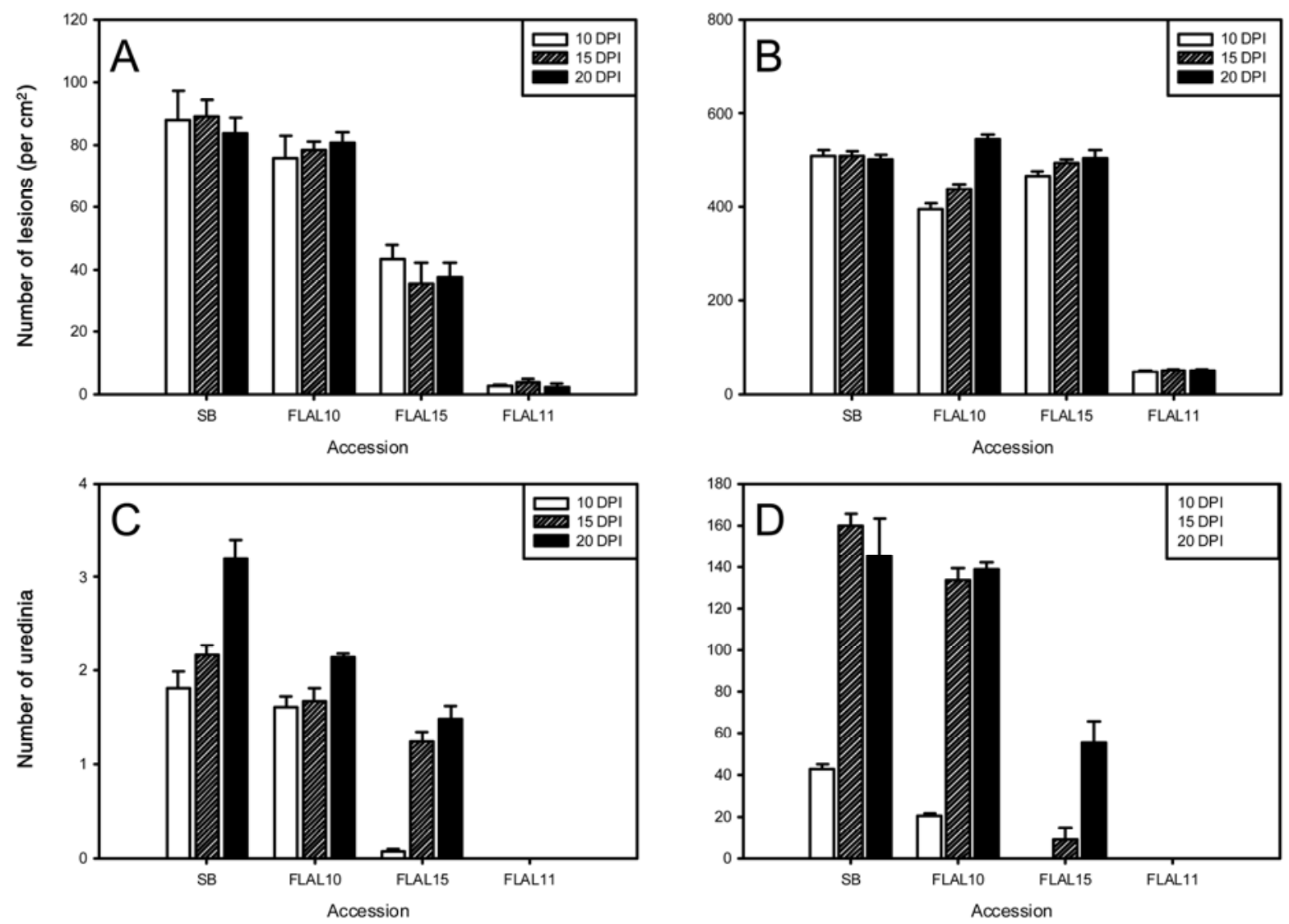

Fig. 3. Characterization of soybean rust lesion density, size and sporulation on detached leaflets from kudzu accessions (FLAL10, FLAL15, and FLAL11) and a susceptible soybean cultivar (SB). A, Number of soybean rust lesions per square centimeter; B, lesion diameter ( $\mu$ m) of soybean rust lesions; C, number of uredinia per soybean rust lesion; and $\mathbf{D}$, number of urediniospores per uredinia. Data were collected 10, 15, and 20 days postinoculation (DPI). Variation in data sets is displayed as standard error bars. 
attempted sites of penetration or by providing a medium for the deposition of toxic compounds $(1,24,36)$. Callose also may play a role in defense by impeding nutrient transfer from host to pathogen or by delaying pathogen growth long enough for other host defenses to become active (3). In potato tubers infected with Phytophthora infestans, fungal growth cessation in incompatible reactions was accompanied by encasement of fungal haustoria with a callose-like material (3). Callose deposition has been reported in soybean in response to infection with $P$. megasperma f. sp. glycinea (8) and between cowpea and the cowpea rust (Uromyces vignae) (35). Further work will be needed to determine the composition of the CWD seen in kudzu and also to ascertain whether the CWD is seen in immune interactions with other kudzu accessions and SBR isolates.

Bonde et al. (7) found that some kudzu accessions that displayed an immune phenotype for a distinct isolate of SBR could display a susceptible or resistant phenotype when challenged with a different isolate. It also was found that the kudzu reacted similarly at individual sites, a phenomenon that we also report here. This result is not surprising given a genetic study conducted by Sun et al. (37), in which microsatellite markers were used to study the genetic diversity within kudzu populations in the southeastern United States It was found that the kudzu populations were genetically diverse among populations but had little diversity within populations, indicating multiple introductions with inbreeding within these populations (37). Given the genetic diversity of the kudzu population and the race-specific response to challenge by SBR isolates, there is likely a host of novel resistance genes within the United States and world kudzu population. These resistance genes could serve as a source of resistance to SBR for incorporation into future transgenic soybean lines.
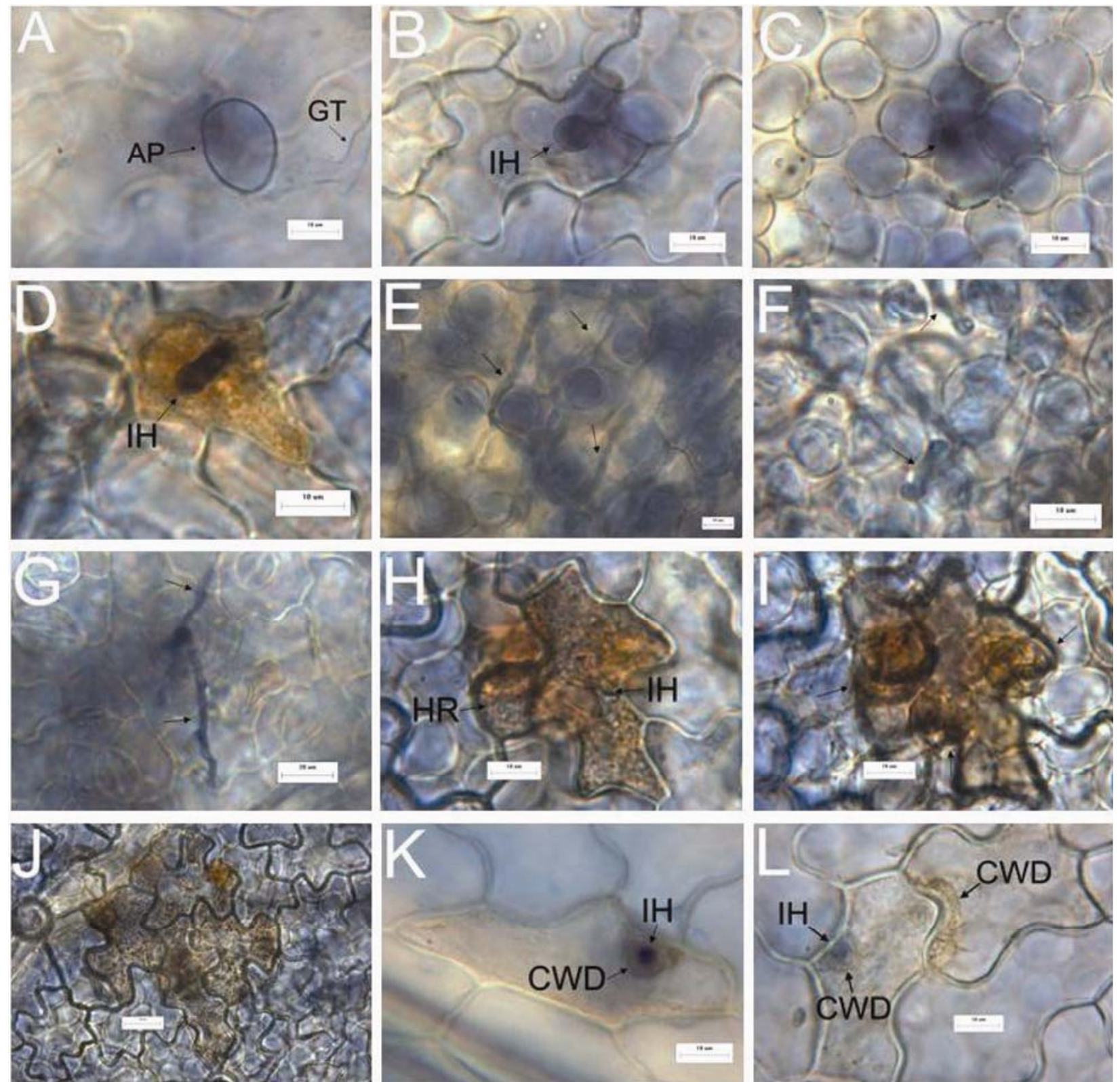

Fig. 4. Interaction between soybean rust isolate FL05 and susceptible (FLAL10), resistant (FLAL15), and immune (FLAL11) kudzu accessions. A, Germ tube (GT) and appressorium (AP) at infection site $24 \mathrm{~h}$ postinoculation (HPI) on FLAL10; B, infection hypha (IH) 24 HPI on FLAL10; C, hyphal growth (arrow) into the mesophyll 24 HPI on FLAL10; D, collapsed epidermal cell and IH 72 HPI on FLAL10; E, colonization of the spongy mesophyll in a soybean leaflet 120 HPI (arrows denote hypha); F, colonization of the spongy mesophyll in FLAL10 (arrows denote hypha); G, hyphal growth (arrows) out of the underside of a leaflet of FLAL10 through a stomatal opening; H, hypersensitive response (HR) of an epidermal cell 48 HPI on FLAL15; I, HR of several mesophyll cells 48 HPI on FLAL15; J, multiple-cell HR 48 HPI on FLAL15; K, HR and cell wall deposition (CWD) around an IH on FLAL11; and L, multiple-cell HR and CWD 48 HPI on FLAL11. 
When scouting kudzu sites for SBR, the pathogen is more likely to be found in shaded areas than in full sun. Leaves expanding and maturing under shady conditions produce a thinner cuticle, potentially making them more susceptible to pathogens that penetrate directly, as does SBR (4). In this study, no significant difference in lesion density was observed between sun and shade leaves using the detached-leaf assay. This suggests that the microclimate in shaded areas may be a more critical factor in rust severity than is cuticle thickness. The age of tissue did not appear

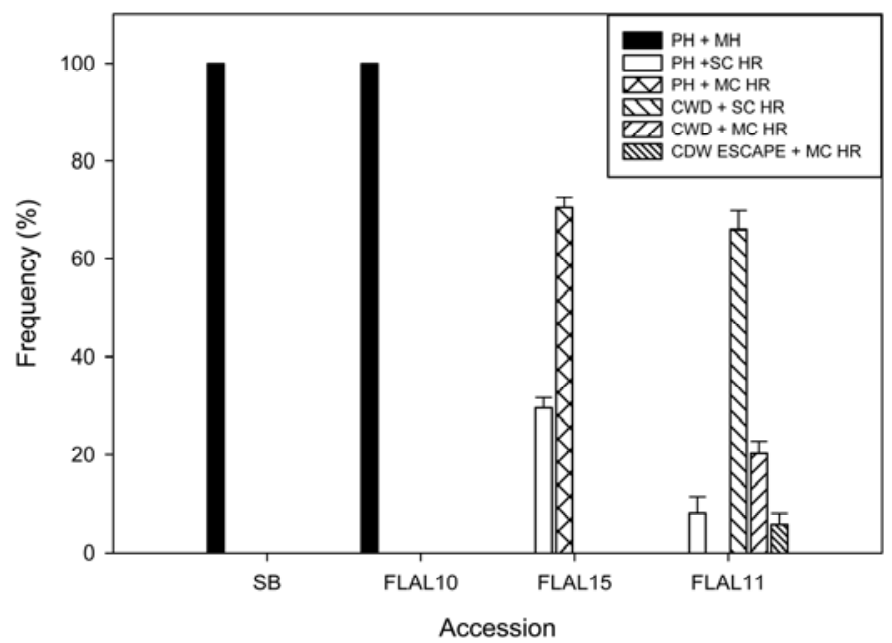

Fig. 5. Frequency of interaction types between soybean rust isolate FL05 and kudzu accessions (FLAL10, FLAL15, and FLAL11) and a susceptible soybean $(\mathrm{SB}) 72 \mathrm{~h}$ postinoculation. Penetration hypha $(\mathrm{PH})$, multiple haustoria $(\mathrm{MH})$, single-cell hypersensitive response (SC HR), multicell hypersensitive response (MC HR), and cell wall deposition (CWD). Variation in data sets is displayed as standard error bars. to have an effect on infection and spore production, because young and mature tissues were equally susceptible.

Considering the reduced number of lesions per diameter, the reduced number of uredinia per lesion, and the reduced number of urediniospores per uredinia at 20 DPI, the resistant accession of kudzu (FLAL11) would contribute $\approx 15 \%$ the amount of inoculum that the susceptible kudzu would contribute in one disease cycle. Because SBR is a polycyclic disease, the amount of inoculum produced in a growing season would be even less in comparison due to the delayed onset of spore production in the resistant accession, because the susceptible kudzu would

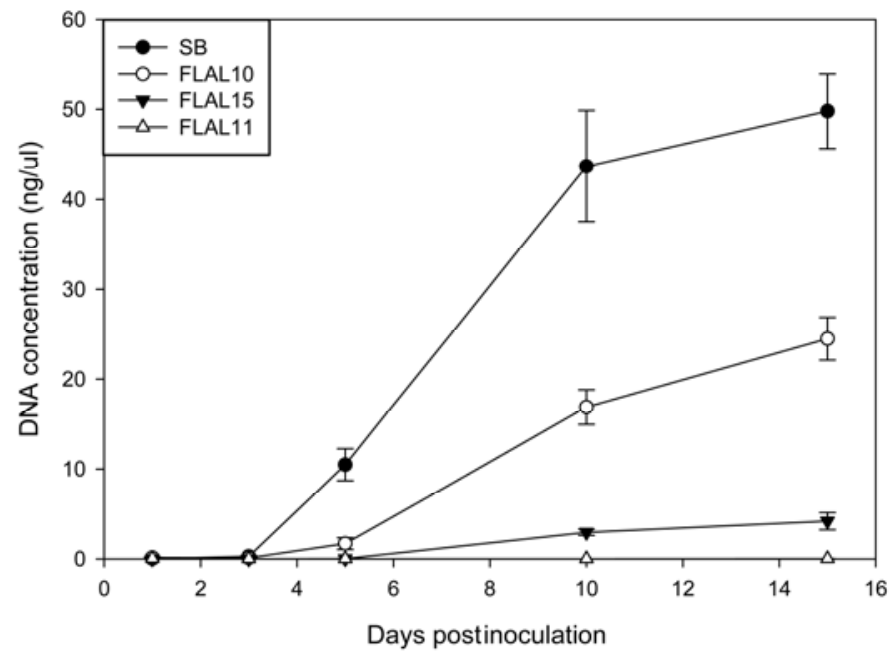

Fig. 6. Measurement of the colonization of kudzu accessions (FLAL10, FLAL15, and FLAL11) and soybean (SB) tissue by soybean rust isolate FL05 using quantitative real-time polymerase chain reaction (qPCR). Detached leaves were inoculated and tissue was sampled $1,3,5,10$, and 15 days postinoculation.
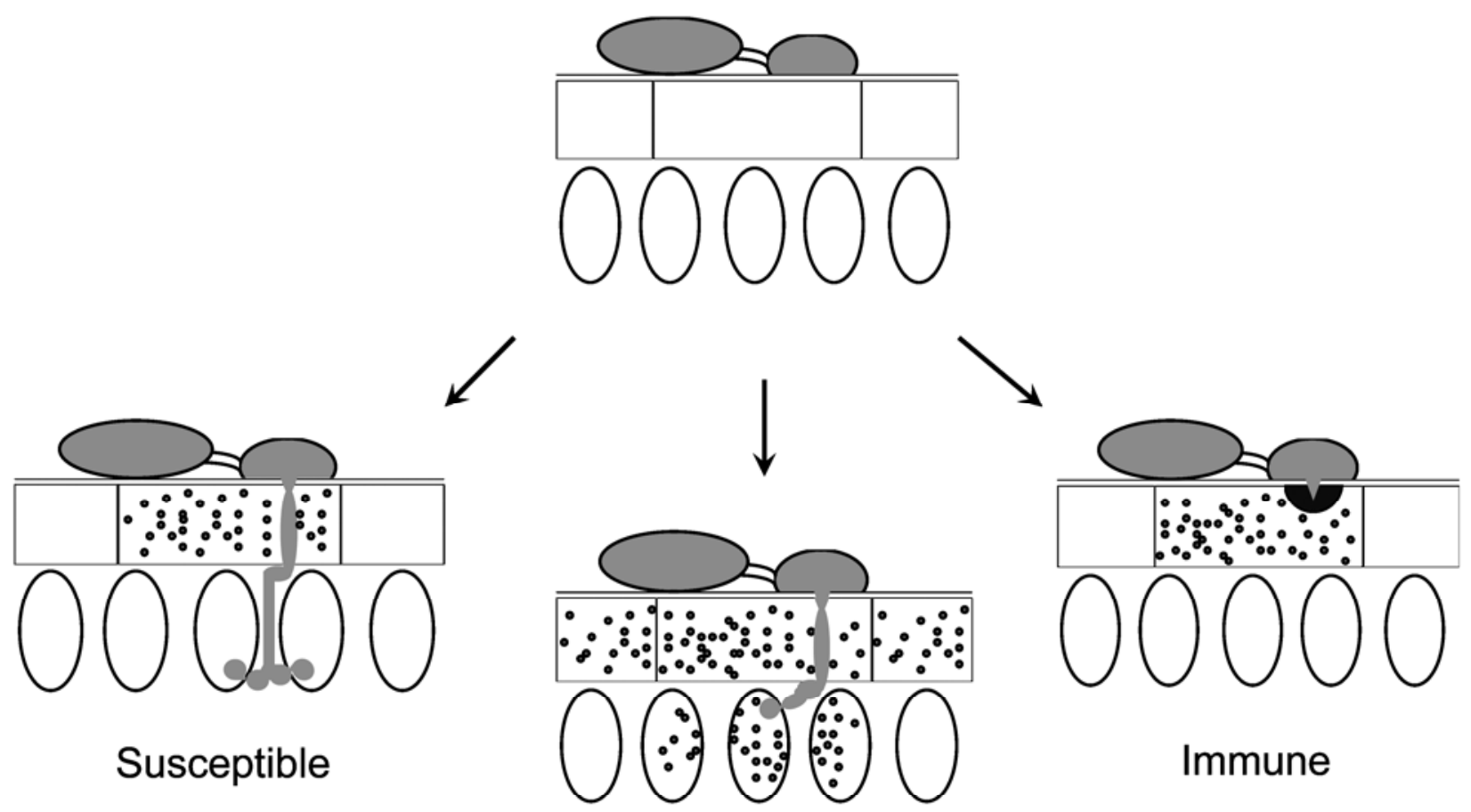

\section{Resistant}

Fig. 7. Diagram of the interactions between soybean rust (SBR) and kudzu. Upon infection, three interactions occur: a susceptible interaction in which the SBR pathogen freely colonizes tissue; a resistant reaction in which a multicell hypersensitive response occurs, limiting colonization and spore production; and an immune reaction, typified by an HR coupled with the encasement of a penetration hypha with a cell wall deposition. Cells that are dead or undergoing an HR are shown with small brown dots representing cytoplasmic granulation and discoloration. 
support a greater number of disease cycles in the same amount of time.

By having an estimate of the prevalence of rust resistance in the kudzu population of north Florida, the potential for overwintering of the pathogen and the inoculum contribution of rust occurring on kudzu may be modeled more accurately. Resistant sites were randomly distributed across the sampled area, a phenomenon also seen by Bonde et al. (7) for kudzu patches in Mississippi, Louisiana, Kentucky, and North Carolina. In this study, $41 \%$ of the kudzu sites examined had resistance, either with reduced spore production or no spore production, to SBR. This value is similar to that reported by Bonde et al. (7), in which the relative amount of resistant kudzu sites was close to $50 \%$. From these two studies, we can probably estimate that $\approx 40$ to $50 \%$ of the kudzu population in the Southeastern United States has some resistance to SBR. More localized information may be beneficial to soybean growers who are interested in removing kudzu patches from around their fields, especially in areas where SBR may become an annually recurring problem. The cost and labor of removing a patch that is relatively resistant or immune might outweigh the benefits of leaving the patch in place. As more kudzu patches in the southeast are scouted and tested, it may be possible to provide further precision in modeling the overwintering and early-season establishment of soybean rust.

\section{ACKNOWLEDGMENTS}

We thank W. Jurick and K. Beckham for help in collecting and maintaining the kudzu accessions and rust isolate and A. Vitoreli for assistance with the qPCR. This work was funded by the North Central Soybean Research Program.

\section{LITERATURE CITED}

1. Aist, J. R. 1976. Papillae and related wound plugs of plant cells. Annu. Rev. Phytopathol. 14:145-163.

2. Akinsanmi, O. A., Ladipo, J. L., and Oyekan, P. O. 2001. First report of soybean rust (Phakopsora pachyrhizi) in Nigeria. Plant Dis. 85:97.

3. Allen, F., and Friend, J. 1983. Resistance of potato tubers to infection by Phytophthora infestans: a structural study of haustorial development. Physiol. Plant Pathol. 22:285-292.

4. Bonde, M. R., Melching, J. S., and Bromfield, K. R. 1976. Histology of the suscept pathogen relationship between Glycine max and Phakopsora pachyrhizi, the cause of soybean rust. Phytopathology 66:1290-1294.

5. Bonde, M. R., Nester, S. E., Austin, C. N., Stone, C. L., Frederick, R. D., Hartman, G. L., and Miles, M. R. 2006. Evaluation of virulence of Phakopsora pachyrhizi and P. meibomiae isolates. Plant Dis. 90:708-716.

6. Bonde, M. R., Nester, S. E., Berner, D. K., Frederick, R. D., Moore, W. F., and Little, S. 2008. Comparative susceptibilities of legume species to infection by Phakopsora pachyrhizi. Plant Dis. 92:30-36.

7. Bonde, M. R., Nester, S. E., Moore, W. F., and Allen, T. W. 2009. Comparative susceptibility of kudzu accessions from the Southeastern United States to infection by Phakopsora pachyrhizi. Plant Dis. 93:593-598.

8. Bonhoff, A., Baldur, R., Golecki, J., and Grisebach, H. 1987. Race cultivar-specific differences in callose deposition in soybean roots following infection with Phytophthora megasperma f. sp. glycinea. Planta 172:101-105

9. Britton, C., Orr, D., and Sun, J. H. 2002. Kudzu. In: Biological Control of Invasive Plants in the Eastern United States. R. Van Driesche, ed. U. S. Dep. Agric. For. Serv. Publ. FHTET-2002-04.

10. Bromfield, K. R. 1984. Soybean Rust. Monograph. No. 11. American Phytopathological Society, St. Paul, MN.

11. Burdon, J. J. 1987. Phenotypic and genetic patterns of resistance to the pathogen Phakopsora pachyrhizi in populations of Glycine canescens. Oecologia 73:257-267.

12. Burdon, J. J., and Marshall, D. R. 1981. Inter- and intraspecific diversity in the disease response of Glycine species to the leaf-rust fungus Phakopsora pachyrhizi. J. Ecol. 69:381-390.

13. Burdon, J. J., and Speer, S. S. 1984. A set of differential Glycine hosts for the identification of races of Phakopsora pachyrhizi Syd. Euphytica 33:891-896.

14. Everest, J. W., Miller, J. H., Ball, D. M., and Patterson, M. 1999. Kudzu in Alabama: History, Uses, and Control. ANR-65. Alabama Cooperative Extension, Auburn.
15. Fears, R. D., and Frederick, D. M. 1977. Kudzu control on forest planting sites. Proc. Southern Weed Sci. Soc. 7:30.

16. Flor, H. H. 1942. Inheritance of pathogenicity in Melampsora lini. Phytopathology 32:653-669.

17. Flor, H. H. 1947. Inheritance of reaction to rust in flax. J. Agric. Res. $74: 241-262$.

18. Flor, H. H. 1955. Host-parasite interaction in flax rust-its genetics and other implications. Phytopathology 45:680-685.

19. Frederick, R. D., Snyder, C. L., Peterson, G. L., and Bonde, M. R. 2002. Polymerase chain reaction assays for the detection and discrimination of the soybean rust pathogens Phakopsora pachyrhizi and P. meibomiae. Phytopathology 92:217-227.

20. Harmon, C. L., Harmon, P. F., Mueller, T. A., Marois, J. J., and Hartman, G. L. 2006. First report of Phakopsora pachyrhizi telia on kudzu in the United States. Plant Dis. 90:380.

21. Hoefle, C., Loehrer, M., Schaffrath, U., Frank, M., Schultheiss, H., and Huckelhoven, R. 2009. Transgenic suppression of cell death limits penetration success of the soybean rust fungus Phakopsora pachyrhizi into epidermal cells of barley. Phytopathology 99:220-226.

22. Jurick, W. M., II, Narvaez, D. F., Brennan, M. M., Harmon, C. L., Marois, J. J., Wright, D. L., and Harmon, P. F. 2008. Winter survival of the soybean rust pathogen, Phakopsora pachyrhizi, in Florida. Plant Dis. 92:1551-1558

23. Kilgore, E. and Heu, R. 1994. First report of soybean rust in Hawaii. Plant Dis. 78:1216.

24. Kovats, K., Binder, A., and Hohl, H. R. 1991. Cytology of induced systemic resistance of cucumber to Colletotrichum langenarium. Planta 183:484-490.

25. Marchetti, M. A., Uecker, F. A., and Bromfield, K. R. 1975. Uredial development of Phakopsora pachyrhizi in soybeans. Phytopathology 65:822-823

26. Miller, J. H. 1985. Testing herbicides for kudzu eradication on a Piedmont site. Southern J. Appl. For. 9:128-132.

27. Miller, J. H., and Edwards, B. 1983. Kudzu: Where did it come from? And how can we stop it? Southern J. Appl. For. 7:165-169.

28. Mitich, L. W. 2000. Kudzu (Pueraria lobata (Willd.) Ohwi). Weed Technol. 14:231-235.

29. Moore, B. 2008. Soybean rust battle takes look at kudzu. Plant Health Progress. Published Online.

30. Piper, C. V. 1920. Kudzu. U. S. Dep. Agric. Dep. Circ. 89:7

31. Pitkin, J. W., Panaccione, D. G., and Walton, J. D. 1996. A putative cyclic peptide efflux pump encoded by the TOXA gene of the plant-pathogenic fungus Cochliobolus carbonum. Microbiology 142:1557-1565.

32. Rytter, J. L., Dowler, W. M., and Bromfield, K. R. 1984. Additional alternative hosts of Phakopsora pachyrhizi, casual agent of soybean rust. Plant Dis. 68:818-819.

33. SAS Institute Inc. 2008. SAS/STAT 9.2 User's Guide. SAS Institute Inc., Cary, NC.

34. Schneider, R. W., Hollier, C. A., Whitam, H. K., Palm, M. E., McKemy, J. M., Hernandez, J. R., Levy, L., and DeVries-Paterson, R. 2005. First report of soybean rust caused by Phakopsora pachyrhizi in the continental United States. Plant Dis. 89:774.

35. Skalamera, D., Jibodh, S., and Heath, M. C. 1997. Callose deposition during the interaction between cowpea (Vigna unguiculata) and the monokaryotic stage of the cowpea rust fungus (Uromyces vignae). New Phytol. 136:511-524.

36. Skou, J. P., Jorgensen, J. H., and Lilholt, U. 1984. Comparative studies on callose formation in powdery mildew compatible and incompatible barley Hordeum vulgare. Phytopathol. Z. 109:147-168.

37. Sun, J. H., Li, Z. C., Jewett, D. K., Britton, K. O., Ye, W. H., and Ge, X. J. 2005. Genetic diversity of Pueraria lobata (kudzu) and closely related taxa as revealed by inter-simple sequence repeat analysis. Weed Res. 45:255-260.

38. Sun, J. H., Liu, Z. D., Britton, K. O., Cai, P., Orr, D., and HoughGoldstein, J. 2006. Survey of phytophagous insects and foliar pathogens in China for a biocontrol perspective on kudzu, Pueraria montana var. lobata (Willd.) Maesen and S. Almeida (Fabaceae). Biol. Control 36:22-31.

39. Tabor, P., and Susott, A. 1941. Zero to thirty million mile-a-minute seedlings. Soil Conserv. 7:61-65.

40. USDA. Plants profile; Pueraria montana (Lour.) Merr. retrieved from the United States Department of Agriculture website. http://plants.usda.gov/ java/profile?symbol=PUMO.

41. Windberry, J. J., and Jones, D. M. 1973. Rise and decline of the 'miracle vine': kudzu in the southern landscape. Southeast. Geogr. 13:63-67.

42. Yang, X. B., Dowler, W. M., and Tschanz, A. T. 1991. A simulation model for assessing soybean rust epidemics. J. Phytopathol. 133:187-200.

43. Yorinori, J. T., Paiva, W. M., Frederick, R. D., Costamilan, L. M., Bertagnolli, P. F., Hartman, G. E., Godoy, C. V., and Nunes, J., Jr. 2005. Epidemics of soybean rust (Phakopsora pachyrhizi) in Brazil and Paraguay from 2001 to 2003. Plant Dis. 89:675-677. 